\section{War Boy to War Horse May Hill Arbuthnot Lecture}

\author{
By Michael Morpurgo
}

British native and novelist Michael Morpurgo, author of War Horse, delivered the 2013 May Hill Arbuthnot Lecture, hosted by Nazareth College and the Youth Services Section of the New York Library Association last spring.
$\mathrm{T}$ o be invited here, to the land of the free, to the country of Henry Longfellow and John Steinbeck and Mark Twain and quite a few others besides, and speak to this conference dedicated to bringing books to children and children to books, is for me an almost singular honor-as a British writer for children. I'm told that only Philip Pullman from across the pond has been here before me to give the May Arbuthnot Lecture. A hard act to follow, but I will do my best.

I have to say that I was at first somewhat reluctant to accept this honor and this invitation, not simply because it's such a really long way from Devon, England, where I live, but because I don't really do lectures as such. I talk to people. I tell people stories. Of course, I proselytise unashamedly on the importance of stories in our lives, in the lives of our children in particular. But I tend not simply to talk about it, I like rather to do it, to tell stories. I am first and foremost a story maker, a weaver of tales, a dream-merchant.

So what I don't intend to do today is to expand at length, to wax lyrical, on the benefits that reading (and writing) can bring to our childrenhow poems and stories are a highway to empathy and understanding, how lives without literature are the poorer for it, how democracy itself is undermined unless we are truly literate, how the power of words changes lives, even makes history. The country whose founding fathers composed the Declaration of Independence, where Lincoln gave us his Gettysburg Address, where Martin Luther King Jr. told us, "I have a dream," this country needs no reminder of the power of words to change lives, to make history.

What I can do is take you on a journey that will be new to you, because it is my journey as a child, a man, a father, a teacher, a farmer, a husband, an educator, a storyteller, and story maker. It is my story. I offer it to you as a telling tale of one child who was lucky enough to be helped on his way by the power of words- spoken and written. Nelson Mandela said that we become who we become, achieve what we achieve, only because others have been there alongside us, to nurture and support us, and to give us at the right moment a helping hand, to offer encouragement, inspiration, and advice when we needed it most.

So let's begin with my mother, a very good place to start, as the song goes. I was born in 1943 and grew up in bombed-out London, a war baby. Next to our house there was a bombsite where my brother Pieter and I played — bombsites made grand playgrounds—dens, crumbling walls, creepy crawly creatures in the undergrowth, bird's nests to rob, and a notice saying "Keep Out," which made it all the more exciting to go in, of course. But come bedtime, it was storytime.

My mother, an actress by profession, would come and lie propped up on a pillow between us, book resting on her knees, and read us a story or a poem or two, always one of her favorites, which of course soon became ours-Kipling's Just So Stories ("The Elephant's Child" in particular), Winnie the Pooh, Alice in Wonderland, Toad of Toad Hall, poems by Longfellow, Kipling again, Masefield, de la Mare, Edward Lear, Shakespeare. We simply loved those precious twenty minutes. She passed on her love for us along with her love of the stories and poems. For Pieter and me, these were the best of times, moments in an oasis of wonder and calm. We were cocooned in the magic of words, and in the love of our mother.

The war had taken its toll on everyone. London was a grey, grim place full of fog; its people exhausted by six years of trauma and grief. Every household had lost someone. My Uncle Pieter had been killed in the RAF in 1940, a young man of 21 , an actor like my mother, who never lived long enough to become a father or a grandfather. He was always in the room as I grew up, in a photograph on the mantelpiece, looking down at me. As I speak to you now, his face is 


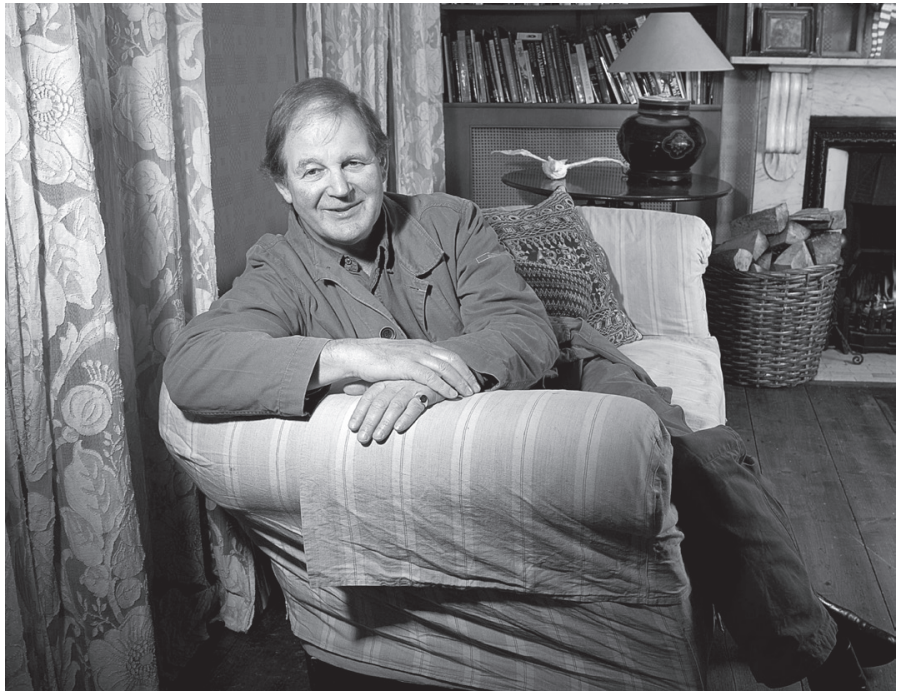

clear in my mind. All my other relatives and friends grew old, changed. Not my Uncle Pieter. Here began, I think, my early awareness of war, the heroism of it (my Uncle Pieter was a hero to me), the sacrifice and the pity of it, too. As I grew I understood further the significance of those bombed-out buildings, of the suffering, of the pain and pride in mother's face whenever the name of Uncle Pieter was mentioned. Such things leave an indelible influence on a young life.

School so nearly cut me off altogether from that early love of stories my mother handed down to me. Almost gone was the fascination of the music of words, and the power of words to make me laugh or cry, think, dream, and wonder. Instead stories simply became texts. Print crowded the pages, to be studied, analyzed, and comprehended. Punctuation tests, spelling tests, handwriting tests, dimmed and then dashed any love of story, killed the magic in the words stone dead. Poems were to be learned by heart, to be recited out loud in front of the whole class. I languished at the back of the class, looked out of the window and dreamed. I longed for playtime, and played rugby at which I excelled and set my heart against books and stories and poems forever. For me they were filled with dread, a fear of failure, and with failure came humiliation, and often punishment.

I was a long time lost in the wilderness at school, focusing almost exclusively on sport by now. But luckily there was one great teacher at my secondary school, high school-the most ancient monastic school in England founded by St. Augustine in the seventh century, where we wore winged collars and straw boaters. This teacher said to me one day, "Michael, there's more to life than sports. Here read this, read it out loud, hear the music in the words." It was a book of Wordsworth poems. I loved it. The music had not died. He gave me the First World War poems of Wilfred Owen, and then Siegfried Sassoon and then Edward Thomas, and said, "Read these, see everything in your mind's eye as you read. Live every word as you read."

I should like to be able to say that I became from that moment on wedded to poetry, an avid reader. Not so, but that old teacher stirred the cinders of the fire my mother had lit all those years before, blown on the embers, and set the flames flickering again.

Then some years later I found myself at university, in London, struggling with my studies in English literature, failing yet again to engage with the subject in a meaningful way, failing to get the grades I needed-it was simply a subject. My heart wasn't in it. Until one day my deeply morose university professor sat himself down on the corner of his desk in his scruffy tweed suit, puffing on his pipe, and began to read us Sir Gawain and the Green Knight. He read it with passion. Utterly absorbed in the poem, he drew us into the world of this ancient language with its strange and wonderful sounds and rhythms. Just like my mother reading me Kipling, he meant it, he loved it. The flames were more than flickering now.

Again I should like to be able to tell you that I became a great reader and scholar from that day on. Not so, I'm afraid. But it was enough to excite me all over again, to get me through university. So that when at last I found myself a year or two later, a teacher in front of a class of thirty-five ten-year-old children, I knew from my old professor, and from my mother before him, what magic there could be in stories, what music there was to be discovered in the words. I knew by this time how to read a story too-you had to love it and mean it, and by now I did mean it. Every story I read to my children I lived. I read them only the books I loved. I read them with passion. From three to half-past every afternoon, I would read them a story to finish the school day, theirs and mine, to send us all home maybe laughing, maybe crying, but always thinking.

Then one wonderful day it all went wrong, in the best possible way. I had begun reading a new book, sure as always that if I gave it my all I could draw them in! But after five minutes, I looked up and saw they were shifting about, looking out of windows, wishing they weren't there, wishing they were home. Disconcerted, I resumed my reading with even greater enthusiasm and commitment. A while later I looked up again. I'd lost them completely. Disappointed with myself and bewildered, I went home and told my wife Clare who was also a teacher. She said that I must absolutely not go in there the next afternoon and bore them all over again.

"Try something different," she said, "Tell them a story of your own, one you've made up yourself. You tell our children stories from time to time-not often enough maybe, but I've listened outside sometimes. They're really quite good, and you're quite a good liar too. What's that except story telling by another name?"

I said, "You've got to be joking. You don't know these ten-yearolds. They're merciless. They'll eat me alive."

“Are you scared?" she asked me.

"Yes," I told her.

"Of telling a story?" she asked. I knew I had been cornered. 
All that night I lay awake late, making up a story for the next day. Three o'clock came round. I screwed my courage to the sticking place (I know that makes Clare sound like Lady Macbeth. She's not at all like that I promise you. But she can be manipulative for the right reasons-and I am glad she is, for as a writer she has always been my first and best supporter, mentor, reader, editor, through good times and bad. She has been the most important of all the people who have helped me on my way, because she has always been there, always had faith.)

There I was in front of the class the next afternoon, no book to read from, no prop, nothing but the story in my head, and me. It took a few minutes to get them on my side. The story, as I remember it, was not great. But I told it with utter commitment. By half past three, I had them eating out of the palm of my hand. The bell went, and then came the best moment of my entire teaching life-a rousing chorus of "Oh sir, go on, sir, finish it, please sir!"

It took me a week to finish that story. I made it episodic, trying to leave each afternoon's episode on a cliff-hanger. On the final afternoon, I saw the head teacher was sitting at the back of my class, her arms folded. She'd heard about Mr. Morpurgo's story and had come to listen.

"Very good Michael, very good," she said afterward. "Now I want you to write it out for me and give it to me on Monday morning." So that's what I did. She sent the story off to a publisher friend of hers at Macmillan-strangely, my publishers in the United States these days, forty-five years later! And I got a letter back, "Dear Mr. Morpurgo, We liked your story, would you consider writing five more? We’ll pay you £75.” Yes! And a year or so later my first book came to me in the post, with my name on it. I was a published author, a real writer, like Dickens, like Wordsworth, like Kipling, like Shakespeare! Eat your heart out, Roald Dahl, I thought.

But I discovered soon enough, much as I loved writing, I did not want to leave teaching. I wanted to do both. The connection and engagement with children, the passing on of stories-my efforts to encourage them to find their own voices as writers had become too important to me for me to abandon.

But now a bigger picture was coming into view. Both Clare and I had become disenchanted with the school system. We could see that those children who were going to succeed, lead fulfilled lives, were doing fine, and would probably do all right without us anyway. They came from homes full of stimuli, with loving, thoughtful, reading parents. They were living life to the full.

But at least half the children we taught came from homes where there were no books, where parents didn't bother, or didn't care or both. These children seemed to be getting very little benefit from school. They were already becoming disillusioned, alienated. We felt their sense of failure and lack of self-worth; their anger, was, if anything, being fueled by the school system. We saw that there was very little we could do at school that might give them hope to change their lives around. They would end up like their parents, disinterested, disenchanted, and become just like them as people, as parents, and so the cycle would go on.

At this point in our young lives, in our late twenties I suppose, my father-in-law, Allen Lane, the great publisher and founder of Penguin Books, had just died. He left Clare some money-he was yet another whose life helped us on our way at just the right moment. We decided to put his legacy where our beliefs were, to try to do something to enrich the lives of those children who needed it most, whose self-worth was at the lowest ebb. But how to do it?

We looked for inspiration to our own childhoods, to our best of times. Clare had had a childhood walking the deep lanes of Devon, as Ted Hughes called them, getting to know and love the wildlife all around her, the farm animals, the people who worked the land. She fed the hens, fed the calves, moved sheep, groomed the horses, rode them, watched salmon and otters and kingfishers down by the river, saw swallows skimming across the fields and a barn owl out hunting at sunset. It was her paradise.

What if, she thought, we tried to make the life-changing experience she had had available for those deprived children, city children mostly, who had never known such things? I was not difficult to persuade. So off we went on our rather naive and idealistic adventure. We moved from the east of England to the west, to a village in Devon called Iddesleigh, the place where Clare had gone on her walks on the wild side and done much of her growing up.

Here in a large Victorian Manor House, we set up our charity Farms for City Children. This was all the way back in 1975. The children, thirty-five or forty at a time, came with teachers, worked alongside us and real farmers, on a proper farm for a week, fed hens, dug potatoes, stomped the fields, watched otters and deer and foxes. And on the night before they went home to London, Birmingham, Bristol, or Plymouth, I would go up and read them my latest story. Stories often inspired by them.

I was, I now discovered, in a rare and privileged position witnessing how the children related to animals, to one another as they were working on the farm, as they were playing. I watched them wide eyed with wonder, saw them grow before my eyes in self-belief and self-worth. Now, and thirty years later, 125,000 children have spent a week of their young lives on one of the charity's three farms-one in Devon, where we still live, one on the Atlantic coast in Wales, and one in Gloucestershire near Bristol. We even have a sister charity near Woodstock in Vermont. Farms for City Kids is what they call it here. New York kids come there, week in week out, to work with the herd of Jersey cows, to help harvest the maple syrup. It's a most beautiful place, a paradise they'll never forget.

The move to Devon to set up the charity focused our lives and my writing as never before. I was twenty nine, with a few books published, none of which were breaking new ground. I was writing within myself, rather superficially. The stories were 
rooted in my teaching, in the children who came to the farm, but somehow not connected enough to me, to my life. I was not digging deep enough. But slowly it became apparent to me that my new life in the countryside, and on the farm, in the village, was not serving simply Farms for City Children, but it was becoming so enriching and was beginning to inform my writing. Like the children, I was learning all the time. Like them, I was wide eyed with it all, drinking in this new world, becoming part of it.

And then there came along two friends and mentors who were to change our lives utterly. They gave us the encouragement we needed to go on with running the charity in those early days when it was struggling, when everyone was advising us that it was hopeless to go on. They gave us the support and friendship we needed, and they gave me-both great writers these twothe confidence to keep writing at a time when my stories were faltering and failing, when manuscripts were being rejected.

The first was a dear old friend of Clare's, almost a grandfather to her: Sean Rafferty, a Scottish poet and our vegetable gardener up at the Victorian House where the city children stayed. He had kept the pub where Clare had grown up as that little girl, her setting-off point for her walks on the wild side. Here's what Sean wrote about the children who came to the farm from the cities, encapsulating the spirit of all we were doing in one brilliant paragraph. Poets can do these things in very few words, even when they write prose:

Children come to the farms in winter and summer, in all seasons, in all weathers. Calves are born, foxes kill the chickens, sheep are dipped and shorn; and all this is not something which they watch-they are involved. THEY feed the hens, hiss at the geese, walk back from the milking parlour in the evening up a dark lane without street lamps, hear owls hoot in the night and are afraid.

Now more than ever it matters that children from the inner cities can experience life in the country. This is a generation which will hear repeatedly of ecological disaster; will be told that the earth itself is threatened. For some of them the earth will not be a globe in the classroom or a map on the wall but a Devon farm where they scuffled beech leaves along the drive and broke the ice on the puddles in the lane. When they are told of polluted rivers it will be one river, which has had its share of pollution, where they first saw a trout jumping and a wading heron, and plastic bags caught in the branches to mark the level of the last great flood.

Last spring, two children went down to the river at dusk to watch for badgers. They did see a badger and they also saw two young otters at play, something many people born and bred in the country have never seen. It was as though Nature herself were choosing her champions.

And the other writer/friend/mentor was the poet laureate Ted Hughes, whom we met when he was fishing on the river that runs through the farm. Ted and his wife Carol became firm and true friends, great supporters of Farms for City Children. Ted's was and is a name to conjure with, so his help to us and to the charity was invaluable and timely. Ted and I collaborated on a book together about the farm and called it All Around the Year, a daily record of life on the farm through the seasons. He wrote poems for each month of the year. Can you imagine how it was for a young writer to work alongside such a master, how inspiring it was? He was ever generous with his time, ever wise in his counseling.

As my confidence as a writer grew, came the beginning of the saga of War Horse, without which it's fair to say I probably wouldn't be here with you today. Many think of it now as my best book and maybe my only book and an instant best seller. It's none of these. It's simply my best-known book, but this had very little to do with me. The story did though.

Here's how the story of War Horse came to be written. I was in the pub one day, about 1979 this was-yes the same pub Clare stayed in as a child, quite a pub this, changes lives, inspires books. I bought a beer and then turned to see an old man sitting by the fire nursing his pint and staring into the flames. I recognized him. I'd met him once or twice maybe, no more. All I knew about him was that as a young man he'd been a soldier in the First World War. Wilf Ellis he was called.

So I sat down opposite and said hello. His smile was welcoming enough, but he didn't want to talk much, I could see that. But I did. I'm like a kid, I'm always asking questions, endlessly inquisitive, particularly when it comes to history. I said, "Wilf, you were in the trenches, weren't you, in the First World War." He nodded, "I was. I was there with the horses."

I thought that was all I was going to get. Wilf, like most people in rural Devon, didn't talk easily. But once he'd started he went on and on and on. For an hour, I sat there and listened, in horror, in amazement, in admiration. His wife said later that he'd never spoken of his time over in France in the war, even to her. I've thought a lot about it since, maybe he was passing his story on. Why he should have chosen to tell me at that moment, I shall never know-maybe he'd heard I wrote stories. As I had said, I'd read the great poems of the First World War as a boy-Wilfred Owen, Siegfried Sassoon, Edward Thomas. As a young man I'd seen the musical play of "Oh What a Lovely War," seen the movies All Quiet On The Western Front and Paths Of Glory.

But here in front of me by the fire was a man who had been there and lived through it. Everything he was telling, he was seeing in his mind's eye as he was speaking, as he took me with him back to 1914, to life and death in the trenches. His account was matter of fact, prosaic even, but every word was meant and felt. It was only when he started talking about his horse that I saw tears coming into his eyes and his voice faltered.

"I tell you something, that horse of mine, he was my best friend. I'd go to see him in horse lines at night to feed him, and I'd stand under the stars and rest my hand on his neck, like warm velvet it was. I'd tell him all my troubles, all my hopes, all my fears, all those things I couldn't talk about with my pals. They had the horror of it in their heads, just like I did, the terror of the next day, and the longing for home. All too close 
to talk about it. But I could tell my horse. He understood, he listened. I know he did. He was a true friend that horse, maybe the best friend I ever had."

Moved beyond belief, I walked home across the fields and told Clare. She suggested I find out more about the horses in WWI. I rang the Imperial War Museum in London.

"How many horses went to the front from our shores during WWI?" I asked. (I didn't know then that many of them had come across from the United States-we simply didn't have enough horses of our own.)

"About a million went," came the reply.

"And how many came back?"

“65,000.”

So, about the same number of horses died as the number of men-on the British side-about 950,000. And they died the same way as the soldiers of course, on the wire, blown to pieces, machine gunned, drowned in the mud. The figures were easy enough to extrapolate. It's thought that on all sides, about ten million soldiers died in the war, 100,000 by the way from here in the United States. So about ten million horses must have died too, on all sides. It was a holocaust of men and horses.

Still reeling from this discovery, I decided to think about writing of one horse in that war. But I didn't want to tell a story of war from one side or the other-that had been done. But maybe, I thought, I could write a novel about the universal suffering in that war (actually in all wars) on all sides.

I dreamed my story up. I would call him Joey after one of the horses on the farm. Have the horse grow up in Iddesleigh in my village, a beloved foal belonging to Albert a farmer's son. Have him sold away to the army by Albert's drunken father against the wishes of the young lad, and have Joey trained as a British Cavalry horse. He's captured in the first cavalry charge of the war, and is then used by the Germans to pull ambulances and guns. He winters on a French farm, is looked after by a young French girl. We see the war raging all about him. Through his eyes we witness as he does, the loss and suffering, the pity of war.

Meanwhile young Albert has joined up to look for him on the Western front. It's a story, yes, of war and suffering, but also of reconciliation and a longing for peace. And at its heart is a story of the love and trust between a boy and his horse, and a horse and his boy. There is only one way to make this work, I thought, the horse will have to tell the story.

But could I really have my story of the First World War told by a talking, writing horse? Wouldn't it be ridiculous and probably very sentimental and anyway too reminiscent of Black Beauty? Don't do it Michael, I told myself. Nothing about that senseless huge war should be sentimental.
Then there was a happening, a miracle I might almost say, that persuaded me I could do it, indeed I should do it, must dare to do it.

I went up to the house to read to a group of city children visiting the farm from Birmingham-the last night of their stay. It was November, rainy, cold. I walked into the darkened stable yard. I saw our horse Hebe, standing by the door of her stable, and just under her head there stood a small boy in bedroom slippers and his pajamas. I was about to tell him to get inside out of the rain when I recognized who he was.

He was called Billy, a child whom I knew had a troubled life, in and out of children's homes and foster families. And Billy did not speak. He'd been at the school for a couple of years, the teachers had told me, and in all that time had not spoken a word. He was withdrawn, deeply troubled, isolated. I'd kept my eye on him all week, and it was true he had not spoken a word. He loved the animals, was easy with them, brave, loving, but silent.

As I watched, I saw he was stroking Hebe's neck humming to her and then he was talking, talking nineteen to the dozen, the words simply flowing. He was telling Hebe all about his day on the farm, how the eggs were warm to touch, how the cows were too smelly. I listened for a moment or two in amazement, then went to find the teachers. They had to see this, hear this. This was miracle enough you might think, but then I noticed something even more miraculous. The horse, I could tell, was listening and understanding, just as Wilf had told me in the pub. No she wasn't understanding the words, of course, but she understood that she had to be there for him, to give him comfort and reassurance. This was reciprocal. Here was a relationship of two sentient beings, a relationship based on respect and love, and yes, understanding. At once I was convinced I could now tell the story through Joey's eyes and it needn't be sentimental. I could do it with integrity. The next day I began to write my story. I began it with a page in the third person-then the rest is Joey's story told by him.

\section{First Page of War Horse}

In the old school, they now use for the village hall, below the clock that has stood always at one minute past ten, hangs a small dusty painting of a horse. He stands, a splendid red bay with a remarkable white cross emblazoned on his forehead and four perfectly matched white socks. He looks wistfully out of the picture, his ears pricked forward, his head turned as if he has just noticed us standing there.

To many who glance up at it casually, as they might do when the hall is opened up for parish meetings, for harvest suppers or even socials, it is merely a tarnished old oil painting of some unknown horse by a competent but anonymous artist. To them the picture is so familiar that it commands little attention. But those who look more closely will see, written in fading block copperplate writing across the bottom of the frame: 


\author{
Joey \\ Painted by Captain James Nicholls \\ Autumn 1914
}

Some in the village, only a very few now and fewer as each year goes by, remember Joey as he was. His story is written so that neither he nor those who knew him, nor the war they lived and died in, will be forgotten.

War Horse came out in 1982 to a few decent reviews but poor sales; I was disappointed. Clare thought it my best book-she still does all these years later. I've written more than a hundred books since and none she says has ever been as good as War Horse. Never marry a truth-teller is my advice, marry a flatterer!

Then came the news that War Horse had been shortlisted for a major literary prize, the Whitbread prize. I was thrilled. My first short-listed book! Things were really looking up, I thought, tuxedo and a long black limousine to London. But as it turned out some other writer won it. The ceremony was televised nationwide, live. I was disappointed of course, but there was some consolation-we had the long black limousine to collect us and take us home; that was something I thought. But it was midnight and Cinderella's limousine was gone. We went back on the Tube, the subway. No prizes for coming second!

Back on the farm down in the dairy at morning milking, the children were very sweet, "We're so sorry, Mr. Morpurgo," they kept saying. Sweet but not tactful. At breakfast later, the phone rang. It was Ted Hughes.

“Let's go fishing Michael,” he said, “Cheer you up.”

We went off for the day, and at no time did he ever even mention the debacle live on television the night before. But at tea that afternoon, after a day spent trying and failing to catch fish, he leaned toward me, "Prizes, Michael," he said, "They're bad for you if you win them, sad for you if you don't. Not important. What's important is that War Horse is a fine book. And I'm telling you Michael, you'll write a finer one. Now forget all about it."

That helping hand again just at the right moment. I've never forgotten his words. Who knows if I've written a finer one? I hope so. Sadly Ted's wonderfully encouraging words didn't improve the sales of the book. It was translated into one or two languages, and by Greenwillow in the United States, where it was very soon out of print. My publishers in London, bless their hearts, kept this in print, just over twenty-five years. I don't think it ever sold more than fifteen hundred copies a year. So there was Joey out at pasture on my backlist and living an unknown, undistinguished, and undisturbed life.

I wrote a sequel, Farm Boy, actually my favorite book, by the way, but nothing much else happened with War Horse, a radio play here, a CD recording there, an attempt to write a film script that never came to anything.
Then out of the blue seven years ago I got a call from Tom Morris, a director at the Royal National Theatre in London, maybe the most prestigious theatre in London.

"We want to make a play of your book War Horse," he said. "Grand," I said trying to contain my excitement.

“With puppets," he went on. "Puppets!”

I felt so disappointed. This could never happen, I thought. Here's yet another theatre director with an absurd pipe dream. How could puppets possibly carry Joey's story through all the devastation of the First World War. "Come up to London Michael," Tom went on, "I've got something to show you."

Of course I went. So there I was sitting in the National Theatre a few days later and watching on a tiny screen a black and white video of a puppet, a giant life-size, skeletal, giraffe puppet, striding, gliding across the stage, with three puppeteers clearly visible operating it. But as I looked a magical thing was happening, they weren't operating it, they were becoming the giraffe. They were living, breathing giraffe. I was at once so moved, and at once utterly convinced of what Handspring puppets could do, what they could do to bring Joey and Topthorn, and a goose and swallows and crows, to life, that War Horse could be produced on stage, and with puppets too.

It took two years of workshopping the play before it was ready. Tom Morris and Marianne Eliot and Sir Nicholas Hytner gathered together some of the most talented people in British Theatre to support Handspring's puppets, Rae Smith the designer, John Tams, and Adrian Sutton for the songs and the music. Here's one of the songs from the show, my favorite. That's why I'm going to sing it. I hope you like it too. (sings the song)

On first night, after a glitch or two in previews, the one thousand-strong audience rose to their feet as one, and wept and clapped. The National Theatre had a hit on their hands, the greatest and most unexpected hit they had ever had. Over four million people have seen it now, worldwide. It won five Tonys in New York, played in Toronto as well, and then went on a tour across America. It's still on tour. It's playing in Australia and New Zealand, and, of course, Joey trots on still in London. So here was another of those friends, Tom Morris and the National Theatre team who gave War Horse, Joey, and me a helping hand at the right moment.

And joy of joys, the play opens in Berlin this autumn, in German, thence to Paris and Amsterdam. So, one hundred years after German troops marched down the Unter Den Linden to war, one hundred years after the British went across the seas to defend little Belgium, and millions of French soldiers were mobilized, and the whole ghastly conflict began, dragging the United States and the entire world into it, there will be a play on in Berlin about universal suffering of war and about reconciliation. 
Ruth M. Baldwin Papers.

22. Ruth M. Baldwin to Elisabeth Baldwin, October 10, 1953, Ruth M. Baldwin Papers.

23. Ruth M. Baldwin, Diary, October 16, 1953, Ruth M. Baldwin Papers.

24. Ruth M. Baldwin, unpublished memoir, no date, Ruth M. Baldwin Papers.

25. Ibid.

26. Ibid.

27. Ibid.

28. Ibid.

29. Ibid.

30. Margaret Peters to Cynthia Baldwin, January 21, 1990, Ruth M. Baldwin Papers.

31. Margaret Peters to Rita Smith, November 19, 1993, Ruth M. Baldwin Papers.

32. Gowan, personal interview.

33. Kate Douglas Wiggin, The Bird's Christmas Carol (Boston: Houghton Mifflin, 1888).

34. S. B. Shaw, Children's Edition of Touching Incidents and Remarkable Answers to Prayer (Grand Rapids, MI, S.B. Shaw, 1896).

35. Mrs. P. Lemming to Rita Smith, June 15, 1992, Ruth M. Baldwin Papers.

36. Justin Schiller to Rita Smith, June 22, 1992, Ruth M. Baldwin Papers.
37. John Harris, Poetic Garland (London: J. Harris, 1808).

38. Ruth M. Baldwin, unpublished memoir.

39. Ibid.

40. Gowan, personal interview.

41. Ruth M. Baldwin, unpublished notes, no date, Ruth M. Baldwin Papers.

42. Ruth M. Baldwin to Ken Leach, October 10, 1973, Ruth M. Baldwin Papers.

43. Ruth Baldwin, "The Baldwin Library,” Horn Book, August 1982, 462-63.

44. Gowan, personal interview.

45. Ruth M. Baldwin, circle letter to a group of friends, October 27, 1975, Ruth M. Baldwin Papers.

46. Gowan, personal interview.

47. Ruth M. Baldwin to G.A. Harrer, September 9, 1976, Ruth M. Baldwin Papers.

48. Gowan, personal interview.

49. Robert Singerman, "Report of the Department of Special Collections for 1985-87 Submitted to the Director of the Libraries," February 26, 1988, Ruth M. Baldwin Papers.

50. Ruth M. Baldwin. Diary 1989, Ruth M. Baldwin Papers.

51. Gowan, personal interview.

52. Rita Smith, personal interview with the author, February 2007.

\section{WAR BOY TO WAR HORSE, continued from page 9}

As one theatre goer in London told me, "War Horse is the greatest anthem to peace I've ever seen on a stage." There is no more appropriate place for this story to be played at than in Berlin.

Then, as if the triumph of the play hasn't been enough, Kathy Kennedy, Steven Spielberg's producer, if you please, walks into the theatre in London with her daughter and sees the show. She's blown away, as everyone is. Within a week, Spielberg himself flies over to see it. Within a year he's making the film, which later garnered six Oscar nominations. The book is now in more than forty-five languages and sells really quite well these days, too. Kathy Kennedy and Steven Spielberg, two more helping hands.

How often since have I explored warfare and a longing for peace in my novels-Private Peaceful and the Butterfly Lion again set in the First World War. The Amazing Story of Adolphus Tips, the story of two black G.I.'s who came to Britain, to Devon in 1943, to train and prepare for the D-Day landings, and their relationship with a Devon farming family, and a cat. The Elephant In The Garden-my tale about the bombing of Dresden. The
Mozart Question, which deals with the Holocaust and the Jewish musicians who were forced to play in the concentration camps, and the power of music to sustain us.

Shadow is set in the War in Afghanistan, of an Afghan family fleeing the country and trying to seek asylum in Britain. The Kites Are Flying is a story of hope, where there is seemingly little hope. Set now in Palestine and Israel, it is about children who fly kites of peace over walls, built to protect or imprison, depending on your point of view. There is desperate sadness and grieving in all these stories, but there is always hope too. That's so important not just for children but for us too.

So lecture over-you'll be glad to hear. Story time. This story I'm going to read to you is about conflict but it is also about a librarian, and also the power of books and stories to change lives. Actually in a way it's about people like you and like me, who have made it our life's work to pass on our love of stories and poems to children.

So this is for you. "I Believe In Unicorns." ¿ 